\title{
BACTERIAL CONTAMINATIONS OF INFORMALLY MARKETED RAW MILK IN GHANA
}

\author{
"E.S. DONKOR, K.G. ANING ${ }^{1}$, and J. QUAYE \\ Department of Microbiology, University of Ghana Medical School, Korle-Bu, Accra, ${ }^{1}$ Animal Re- \\ search Institute, Achimota, Accra and ${ }^{2}$ Animal Science Department, College of Agriculture, \\ University of Ghana, Accra.
}

\begin{abstract}
SUMMARY
Background: Milk has an outstanding nutritional quality but is also an excellent medium for bacterial growth and an important source of bacterial infection when consumed without pasteurization.

Objective: To estimate the bacterial health risk of milk consumption in Accra and Kumasi, the two major cities in Ghana.

Method: A total of 96 raw milk samples collected in 2002 from the two sites were cultured and the isolated organisms identified by standard bacteriological methods.

Results: Overall, the organisms identified and their prevalence rates were Yersinia spp. (19.8\%), Klebsiella spp (16.7\%), Proteus spp. (7.3\%), Enterobacter spp. (6.3\%), Escherichia coli (2.1\%), and Staphylococcus spp (14.6\%), Bacillus spp. (11.5\%) and Mycobacterium spp. (1\%). Most of the organisms identified were enterobacteria indicating probable faecal contamination of the milk as a result of poor hygiene. Most of the bacteria identified in the milk sampled are potential foodborne pathogens, and though some of them occurred in few samples, the practice of pooling milk from different sources by traders, and the absence of pasteurization generally observed among them could increase the risk posed by such organisms.

Conclusion: The study has shown that informally marketed raw milk in the two cities could be an important source of infection with a wide range of organisms, particularly enterobacteria. There is the need for instituting effective control measures including improved hygienic handling of milk and its pasteurization to protect public health.
\end{abstract}

Keywords: Bacterial contaminations, raw milk, Ghana.

\section{INTRODUCTION}

Milk has an outstanding nutritional quality, but is also an efficient vehicle for transmission of diseases to humans. Pathogenic bacteria pose a serious

\footnotetext{
* Author for correspondence
}

ericsdon@hotmail.com threat to human health, and constitute about $90 \%$ of all dairy- related diseases ${ }^{1}$. Recent studies have established the emergence of new milk-borne bacterial pathogens such as Escherichia coli O157:H7 with more serious challenges for public health and the diary industry ${ }^{2}$. To protect public health against milk-borne infections, there are regulations that require proper hygienic handling of milk and its pasteurization. However, such regulations are not usually adhered to in developing countries, making milk-borne health risk higher in developing countries.

Informal milk markets involve milk sale through unregulated channels. Such markets account for over $80 \%$ of convenient delivery and lower prices from these informal milk markets ${ }^{3}$. However, there are regulations such as restricting milk handling to cold chain pathways to discourage such markets for public health reasons ${ }^{4,5,6}$ though these regulations are not generally implemented in many countries. In Ghana, studies done on selected farms show that raw milk may be contaminated by a wide range of bacteria, including Staphylococcus aureus, Escherichia coli, Pseudomonas pyocyaneus, Bacillus, and Corynebacterium $\operatorname{spp}^{4,5}$. At present, a major problem facing the diary industry is low demand for raw milk, partly because of public concerns over its safety and quality. However, the extent of risk posed by consumption of raw milk in the country is not well documented. It is submitted that if efforts are made to produce safe and good quality milk, it would not only protect public health, but also stimulate growth of dairy industry in Ghana. This study was carried out to estimate the bacterial health risk associated with informally marketed raw milk in Accra and Kumasi, two major cities in Ghana. The study investigated the agents of milk-borne bacterial infections and the prevalence rates in milk. 


\section{MATERIALS AND METHODS} Milk Production at the Study sites

The study was carried out in Accra and Kumasi, the two major cities in Ghana from March to August 2002. The main cattle breed in these sites, and therefore source of milk in Sanga but West Africa Short Horn and Zebu are also important. Milk production normally starts with the beginning of calving in October, increases slowly as a result of feed becoming scarce due to break in rains. It peaks between March and August when feed increases, by which time calving is completed. From June when most of the calves have been weaned, a sharp decline in milk production occurs. The peak production of raw milk in the areas occur a month after the effective start of the rainy season. Milking of the cow is usually done under poor hygienic condition, usually in the kraals, which are often contaminated with mud, cow dung, and urine, several flies usually surround the milk during milking and it is not unusual to find particles of dirt, dung and some flies in the milk during and after collection.

\section{Sample collection}

A total of 96 raw milk samples were collected from the two sites; 58 from Accra and 38 from Kumasi where accessibility to samples was quite limited. The samples were collected aseptically from market agents and transported on ice to the laboratory for analysis.

\section{Laboratory Analysis}

Laboratory analysis of the milk samples was carried out in the microbiology laboratory of the Animal Science Department of the University of Ghana, Accra, Ghana. For isolation of Mycobacterium, the milk samples were centrifuged at $3000 \mathrm{pm}$ for 15 minutes and about $100 \mu \mathrm{l}$ of the sediment inoculated onto slopes of Lowenstein Jensen medium. The inoculated slopes were incubated at $37^{\circ} \mathrm{C}$ for $2-6$ weeks, and positive cases were confirmed by Ziehl Neilsen staining. One milliliter of each milk sample was also inoculated into peptone broth and incubated at $37^{\circ} \mathrm{C}$ for $18-24$ hours. After incubation, about $100 \mu$ l of the inoculated peptone broth were sub-cultured onto plates of blood agar, MacConkey agar, and salmonella and shigella agar, and further incubated at $37^{\circ} \mathrm{C}$ for 18-24 hours. Bacterial growth produced on the various culture media were stained by Gram staining and examined microscopically. Bacteria colonies suspected to be enterobacteria were purified on nutrient agar and examined biochemically ${ }^{7}$. Identification of bacteria isolated from the milk samples was based on colonial morphology on the various media, staining and microscopy, and results of biochemical tests.

\section{RESULTS}

\section{Milk Bacteria Flora}

Overall, eight bacteria were identified in the milk sampled form the two sites. The bacteria so identified were Yersinia spp, Staphylococcus spp., Bacillus spp., Proteus spp., Escherichia coli, Klebsiella spp. (including E. aerogenes) (Table 1).

Table 1 Bacteria identified in *ninety eight (98) raw milk samples from Accra and Kumasi

\begin{tabular}{|c|c|c|c|c|c|c|}
\hline \multirow[t]{2}{*}{ Bacteria } & \multicolumn{2}{|c|}{ Accra } & \multicolumn{2}{|c|}{ Kumasi } & \multicolumn{2}{|c|}{ Total } \\
\hline & $\mathbf{N}$ & $\%$ & $\mathbf{N}$ & $\%$ & $\mathbf{N}$ & $\%$ \\
\hline $\begin{array}{l}\text { Yersinia spp. } \\
\text { Klebsiella spp }\end{array}$ & 15 & 25.9 & 4 & 11 & 19 & 19.9 \\
\hline Proteus spp. & 0 & 0 & 15 & 39.5 & $* * 15$ & 15.6 \\
\hline $\begin{array}{l}\text { Enterobacter } \\
\text { spp. }\end{array}$ & 7 & 12.1 & 0 & 0 & 7 & 7.3 \\
\hline $\begin{array}{l}\text { Escherichia } \\
\text { coli }\end{array}$ & 0 & 0 & 6 & 15.8 & +6 & 6.3 \\
\hline $\begin{array}{l}\text { Staphylococcus } \\
\text { spp. }\end{array}$ & 1 & 1.7 & 1 & 2.6 & 2 & 2.1 \\
\hline Bacillus spp. & 14 & 24.1 & 0 & 0 & 14 & 14.6 \\
\hline \multirow{2}{*}{$\begin{array}{l}\text { mycobacterium } \\
\text { spp. }\end{array}$} & 11 & 19 & 0 & 0 & 11 & 11.5 \\
\hline & 1 & 1.7 & 0 & 0 & 1 & 1 \\
\hline Total & 49 & 84.5 & 26 & 68.9 & 75 & 78.2 \\
\hline $\begin{array}{l}\text { * samples sizes from } \\
\text { **included K. pneun } \\
\text { Klebsiella spp. (1) } \\
\text { +included E. aerogen }\end{array}$ & $\begin{array}{l}\text { cra a } \\
\text { niae }(\end{array}$ & $\begin{array}{l}\text { Kumas } \\
\text { K. oxy }\end{array}$ & $\begin{array}{l}\text { ere } 5 \\
\text { a }(2),\end{array}$ & $\begin{array}{l}\text { Ind } 38 \mathrm{r} \\
\text { ozaen }\end{array}$ & $\begin{array}{l}\text { (7), and } \\
\text { (7) anely }\end{array}$ & \\
\hline
\end{tabular}

The overall prevalence rates of the organisms were $1.0-19.3 \%$. The prevalence rates of the various bacteria identified in milk for Accra and Kumasi were $1.7-25.9 \%$ and $2.6-39.5 \%$ respectively. The most prevalent organism overall was Yersinia spp., while the least prevalent was Mycobacterium spp.

\section{DISCUSSION}

Bacteria are widely distributed in nature and may be introduced into milk easily. Consequently, a broad spectrum of bacteria can be present in milk as observed in this study. All the bacteria identified in the milk samples are potentially pathogenic. However, some of them including Proteus and the various Klebsiella spp. are rarely associated with foodborne infections. Klebsiella pneumoniae, the main klebsiella pathogen causes pneumonia while proteus is mainly associated with wound and urinary tract infections. Thus the occurrence of these organisms in milk may not pose risk to consumers. Most of the other bacteria identified in the study 
have been implicated in milk and other food related infections 9 . Though in this study, some of them such as Mycobacterium spp. and Escherichia coli occurred in few samples, the practice of pooling milk from different sources, and the fact that only about $10 \%$ of milk traders pasteurize or heat milk before sale, could increase the risk posed by such organisms ${ }^{8,10}$. In Ghana because food related infections are not well investigated, little is known about the transmission of these organisms and other food pathogens to humans.

Bacillus and staphylococcus are associated with food borne intoxication through production of enterotoxins, and the main agents involved here are Bacillus cereus and Staphylococcus aureus ${ }^{1}$. Bacillus cereus may be introduced into milk from the soil, cattle feed, milking equipment, and the udder, while Staphylococcus aureus could come from the udder or skin of humans. Bacillus cereus is able to produce spores which can survive pasteurization. Similarly, the enterotoxin produced by Staphylococcus aureus is also heat stable and can also survive pasteurization ${ }^{11}$. Apart from Escherichia coli, which has some toxin producing strains, the other food related pathogens identified in the milk samples hardly produce toxin, neither do they form spores. Thus infections from these organisms through milk can be controlled fully through pasteurization. The occurrence of pathogenic bacteria in milk could come from various sources including the infected cow ${ }^{12}$, and in Ghana, various cattle infection such as brucellosis and tuberculosis have been documented ${ }^{13}$.

Most of the organisms identified were enterobacteria. Enterobacteria are common inhabitants of the intestinal tract of various domestic animals including cow, and are commonly found in cow dung which was observed to be abundant at the milking environments, and therefore easy contamination of the milk as a result of poor sanitation of the kraals or milking environments.

Owing to lack of resources a limited number of media and biochemical reagents were used in the laboratory investigation of the milk samples. This could account for the non-detection of organisms such as Mycobacterium.

The study has shown that informally marketed raw milk in the two cities could be an important source of infection with a wide range of organisms, particularly enteric pathogens. An important source of microbial contamination of the milk is faecal pollution probably from cow dung. There is the need for instituting effective control measures to protect public health. This includes mandatory milk pasteurization by traders and improved hygienic handling of the commodity during milking, ensuring milking is not done on cow dung. There is also the need to carry out a similar study with raw milk not sold through informal chains to assess the health risk. Such milk is usually produced by farms of the Universities and Ministry of Agriculture in Ghana.

\section{ACKNOWLEDGEMENT}

The authors are grateful to Mr. Cornelius and Stephen Ogbete of the Pathology Department of the Animal Research Institute for the technical assistance offered.

\section{REFERENCES}

1. Ryser ET. Public Health Concerns. In: Applied Diary Microbiology; Steele Edition. Mercell Dekker, Inc New York. 1998; 263404.

2. Sivapalasingams S, Friedman CR, Cohen L and Tauxe RV. Fresh produce: a growing cause of outbreaks of foodborne illness in the United States. J Food Protect 2004; 67(10): 2342-2353.

3. Omore AO, Muriuku H, Kenyanjui M, Owango $\mathrm{M}$ and Staal S. The Kenyan Dairy Subsector. A rapid appraisal. Research Report of the MoA/KARI/ILRI Small holder Dairy (R\&D) Project. Internationally Livestock Research Institute, Nairobi Kenya. 1999.

4. Abraham CA and Laryea AM. Preliminary investigation of the bacteriology of raw milk produced on the Accra plains. Ghana Med J 1968; 7: 100-103.

5. Ayebo D, Assoku RKG and Oppong ENW. A study of the bacteriology of raw milk produced on the Accra Plains of Ghana. Ghana $J$ Sci 1976; 16: 9-18

6. Kivaria FM, Noordhuizen JP, and Kapaga AM. Evaluation of the hygienic quality and associated public health hazards of raw milk marketed by smallholder dairy producers in the Dar es Salaam region. Tanzania. Trop Anim Hlth Prod 2006; 38(3): 185-194

7. Baron JE, Peterson LR, and Finegold SM. Bailey and Scott Diagnostic Microbiology; $9^{\text {th }}$ Edition CV Mosby Co. 1994; 362-385. 
8. Aning KG, Sampane-Donkor E, and More A. Analysis of milk-borne health risks in milk markets in Ghana. DFID Peri-urban and dairy project report. Animal Research Institute, Accra, Ghana. 2002.

9. WHO. Bacterial diseases transmitted through milk. WHO report. WHO Geneva. 1962.

10. Kleeberg HH. Human tuberculosis of bovine origin in relation to public health. Rev Sci Tech of Intl Epidem 1984; 3:11-23.

11. Vasavanda PC, and Cousin MA. Dairy microbiology and safety. In: Dairy science and technology hand book; edited by Hui YH (Product Manufacturing. VCH-Publishers, new York, federal Republic of Germany, UK. 1992; 2: 330-360.

12. Oliver SP, Javarao BM, and Almeida RA. Food borne pathogens in milk and the dairy farm environment: food safety and public health implication. Food borne Pathog Dis 2005; 2(2): 115-129.

13. Aning KG. Public health issues. In: Milk marketing, processing and public health in Ghan: A review of literature. Animal Research Institute, Accra, Ghana. 1999. 